\title{
Expression of Oxidative Enzymes in Cotton Plant under Biotic Stress
}

\author{
Ayesha Tariq ${ }^{1}$, M. Rizwan' ${ }^{2}$, Muhammad Kamran Rafique ${ }^{3}$, Syed Naeem Sajid ${ }^{3}$, Zarmeen Fatima ${ }^{4}$, Ummul \\ Buneen $^{3 *}$, Imtiaz Hussain ${ }^{3}$, Hamza Akram ${ }^{3}$, Sidra Ray ${ }^{3}$ \& Haseeb Haroon ${ }^{5}$ \\ ${ }^{1}$ Department of Biochemistry, University of Agriculture Faisalabad, Pakistan \\ ${ }^{2}$ Department of Plant Breeding and Genetics, University of Agriculture Faisalabad, Sub Campus Burewala, Pakistan \\ ${ }^{3}$ Centre of Agricultural Biochemistry and Biotechnology, University of Agriculture Faisalabad, Pakistan \\ ${ }^{4}$ Department of Bioinformatics and Biotechnology, Government College University, Faisalabad, Pakistan \\ ${ }^{5}$ National Institute of Food Science and Technology, University of Sargodha, Pakistan.
}

Corresponding author: Ummul Buneen E.mail: ummul.buneen96@gmail.com

DOI: 10.29322/IJSRP.10.05.2020.p10156

http://dx.doi.org/10.29322/IJSRP.10.05.2020.p10156

\begin{abstract}
Cotton leaf curl disease caused by the Cotton Leaf Curl Gemini Virus (CLCuV) is limited to Asia and Africa. This study was conducted in green house to check the role of antioxidant enzymes under diseased conditions. Four cotton cultivars (Gossypium hirsutum) were planted with two replications to check the expression in healthy and disease infected plants. The estimations of total soluble protein contents and the activities of peroxidases (POX), catalases (CAT), proteases and superoxide dismutase (SOD) were studied in leaves with 8 genotypes of cotton, four susceptible and four are disease infected. Disease symptoms were shown less intense in disease infected genotypes but severe in highly susceptible genotypes. The results showed that protein, POX, CAT, proteases and SOD played major role in disease resistance against CLCuV. The SOD, protein contents and CAT activities showed lower values in disease infected genotypes while they decreased significantly in susceptible genotypes. The CAT was found to be increased in both genotypes with high percentage in infected genotypes as compared to healthy. The results showed that significantly higher concentrations of total phenols and higher activities of protease the SOD, CAT and TFC in disease infected genotypes after infection with CLCuV. Statistically the ANOVA was performed to check the levels of above mentioned enzymes against plant resistance. These findings could be considered as biochemical markers for studying plant-virus compatible and incompatible interactions.
\end{abstract}

Key words: Cotton leaf curls virus, G. hirsutum, disease index, disease incidence, whitefly, antioxidant enzymes, and biochemical compounds.

\section{INTRODUCTION}

\subsection{Introduction of cotton}

Cotton is a well-known and most important industrial crop worldwide which is grown more than 80 countries in tropical and subtropical regions. Cotton word derived from Arabic word "qutun".It is also known as "Kapas" in Pakistan and India which is derived from a Sanskrit and "Karparsa" (Lee, 1984; Smith, 1995). Cotton plays a vital role in agronomy and agriculture economy. The total world cotton production almost $50 \%$ comes from two countries China and India (Alkudssi et al., 2013). 
Table 1.1: List of top 10 cotton producer countries

\begin{tabular}{|c|c|c|c|c|}
\hline \multicolumn{5}{|c|}{ Top 10 Cotton Producing Countries (in metric tonnes) } \\
\hline Rank & Country & 2010 & 2011 & 2012 \\
\hline 1 & China & $5,970,000$ & $6,588,950$ & $6,840,000$ \\
\hline 2 & $\underline{\text { India }}$ & $5,683,000$ & $5,984,000$ & $5,321,000$ \\
\hline 3 & $\underline{\text { United States }}$ & $3,941,700$ & $3,412,550$ & $3,598,000$ \\
\hline 4 & Pakistan & $1,869,000$ & $2,312,000$ & $2,215,000$ \\
\hline 5 & Brazil & 973,449 & $1,673,337$ & $1,638,103$ \\
\hline 6 & Uzbekistan & $1,136,120$ & 983,400 & $1,052,000$ \\
\hline 7 & Turkey & 816,705 & 954,600 & 851,000 \\
\hline 8 & Australia & 386,800 & 843,572 & 973,497 \\
\hline 9 & Argentina & 230,000 & 295,000 & 210,000 \\
\hline 10 & Turkmenistan & 225,000 & 195,000 & 198,000 \\
\hline
\end{tabular}

\section{Cotton production in different countries}

Cotton is commercially developed in the tropical and mild regions of more than 100 countries. Cotton in Pakistan, India, USA and China are the best production. Cotton has an extended commerce around the worlds of hundreds billions. China has an important source of income from cotton and constitutes 100 million agricultures and in textile industry 19 million labors work and in related industries (Zhu et al., 2011). Fiber exchange is not as it were thing on cotton business based; in oil de-lined cotton seed are handled, bodies and super (up to $41 \%$ of protein), (Campbell et al., 2010).

\section{Kinds of Cotton}

Four types of cotton are discussed in this dissertation:

- Gossypium arboreum

- Gossypium barbadense

- Gossypium herbaceum

- Gossypium hirsutum

Cotton (Gossypium spp.) is a primary source of meal, protein, natural oil and textile fiber. Many countries are producing high yields of cotton. Large scale producers of cotton including Pakistan, United States, India and China around the globe more than $70 \%$ of the total cotton production contribute. Amongst the 50 Gossypium species, two diploid species $(G$. arboreum and $G$. herbaceum) and two tetraploid species ( $G$. barbedense and G.hirsutum) are universal, but overall cotton production for G. hirsutum is more than $90 \%$ of the rest of all species ( Lee et al., 2007). Also called "white gold" cotton could be a delicate, staple fiber that develops in a form known as boll around the seeds of the cotton plant Gossypium sp. In the middle of the $18^{\text {th }}$ century Gossypium named by Linneaus and it is related to the Malvaceae family (Smith, 1995). Its global distribution induced an impressive diversification in terms of morphology (seeds, trichome), physiology and ecology. This diversification led to a remarkable evolution at the chromosome level (substantial evolution of chromosome size and structure) (Endrizzi et al., 1985; Wendel and Grover, 2015).

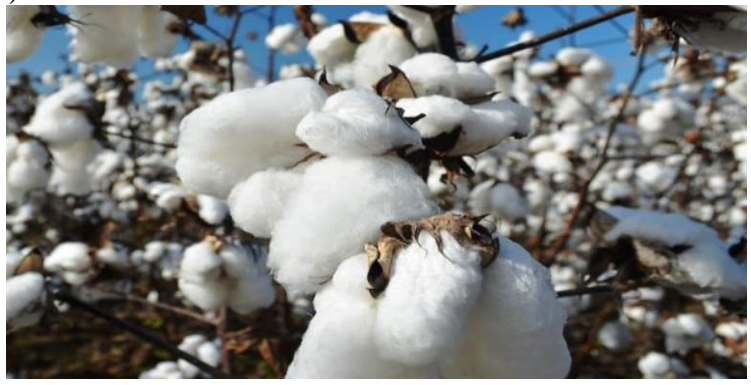

Fig. No 1. White- gold cotton

The industrial and agricultural economy of the country cotton plays a vital role in fiber and cash crops. It provides the basic raw material (cotton fiber) to cotton textile industry.

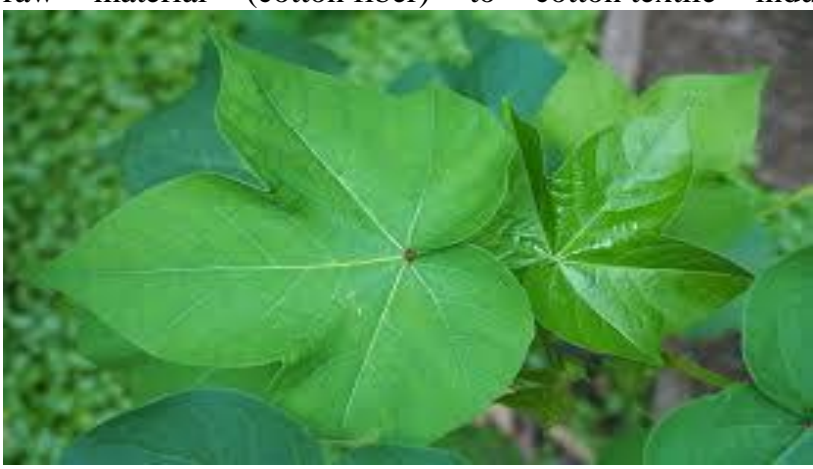

Fig. No 2. Leaves of tetraploid cotton species

The Gossypium genus contains about 45 diploid species with 26 chromosomes and 5 tetraploid species and in which 52 pairs of chromosomes (Brubaker et al., 1999). The reason for the development of different number of sets of chromosomes 
seems to be due to different origins of these organisms. $G$. hirsutum originated from Central America and G. barbadense originated from Peru (Lubbers et al., 2009). Cotton plant has remained very useful in the history as it was the source of food and fiber (Cantrell, 2005). There are almost 51 species of the genus Gossypium (Hendrix et al., 2005). Different species of the genus Gossypium are having different number of sets of chromosomes, like Gossypium arboreum L. being diploid have two sets (2n) and Gossypium hirsutum L. being tetraploid have four sets $(4 \mathrm{n})$ and Gossypium barbadense L. is allotetraploid (8n) (Wendel and Cronn, 2003).

The most developed species from these two forms is $G$. hirsutum because it produces quality fibers in all respects. The local species of cotton G. herbaceum and G. arboretum are both diploid which do not produce as much quality fiber as tetraploid species. The interesting fact about diploid forms of cotton plants is that these are resistant to $\mathrm{CLCuV}$ and these have adapted themselves to the hot and dry climate which increases their demand in the cotton business (Akhtar et al., 2010). In any case the yield of cotton is disadvantageous influenced by biotic and abiotic stresses. Therefore, an effort to examine the molecular adjustment mechanisms of stresses and to reinforce push resistance in this plant is of essential importance to upgrade cotton production (Bota et al., 2004).

\section{Gossypium Arboreum}

Gossypium is a blooming plant within the tribe Gossipieae of the mallow family, Malvacea from which cotton is harvested. It is local to tropical and subtropical areas of old and unused world.

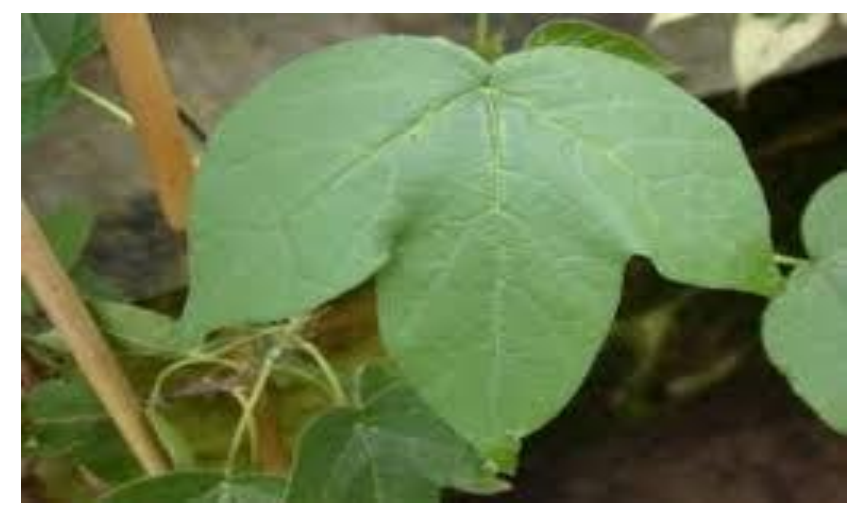

Fig. No 3. Leaves of Gossypium arboreum

G. arboreum L. is not only to make sure a importance of hypothetical vile for preserving the Asiatic cotton germplasm assests, while moreover to recognize and appropriate progress , perfect characteristic in which yield and different plant structures that cutting edge of cotton plant that can be misused (Verma et al., 2014).

\section{Gossypium hirsutum}

Cotton Gossypium hirsutum L is a plant fiber of major financial significance, with seeds giving an extra source of protein in human and instinctive nourishment. Flavonoids play a dynamic role in maintaining plant health and much research has examined the part of flavonoids in plant protection and plant energy and the impact these have on cotton generation (Nix et al., 2017). Gossypium hirsutum is the most abundant species of all other kind of cotton species. It shares about $90 \%$ of the world's cotton. Gossypium barbadense is on second position which shares $8 \%$ of the all while Gossypium herbaceum and Gossypium arboreum share only $2 \%$ in the world's cotton (Jiang et al., 1998).

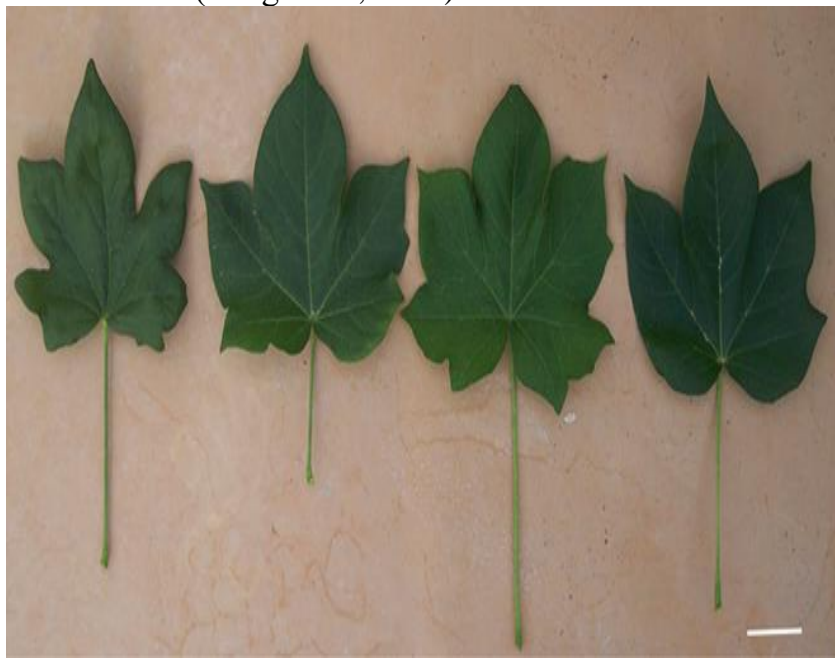

Fig. No 4. Gossypium hirsutum samples from NIBGE

In spite of the fact Gossypium arboreum, that it provides small surrender while it has numerous imperative characteristics for example various disease, many insects tolerant and illness and high fiber quality and extraordinary versatility, which are missing in G. hirsutum, while close to G. arboreum can be developed beneath modest conditions and less overseen range. Cotton is infected by more than a few insects, pests and pathogens inducing diverse infections. Cotton leaf curl virus $(\mathrm{CLCuV})$ is the greatest harmful infection, causing colossal injured the cotton plant in among them (Khan and Ahmad, 2005). All provinces of the Pakistan CLCuV have spread out with the passage of time (Tariq, 2005). Whitefly Bemisia tabaci is a cause of transmission of cotton leaf curl disease and the causal agent may also reside in other insects (Khan and Ahmad, 2005). As described by many model studies by controlling the attack of Whitefly Bemisia tabaci which is the main vector of the infection, subsequent onset of diseaseCLCuD can be checked (Holt et al., 1999).

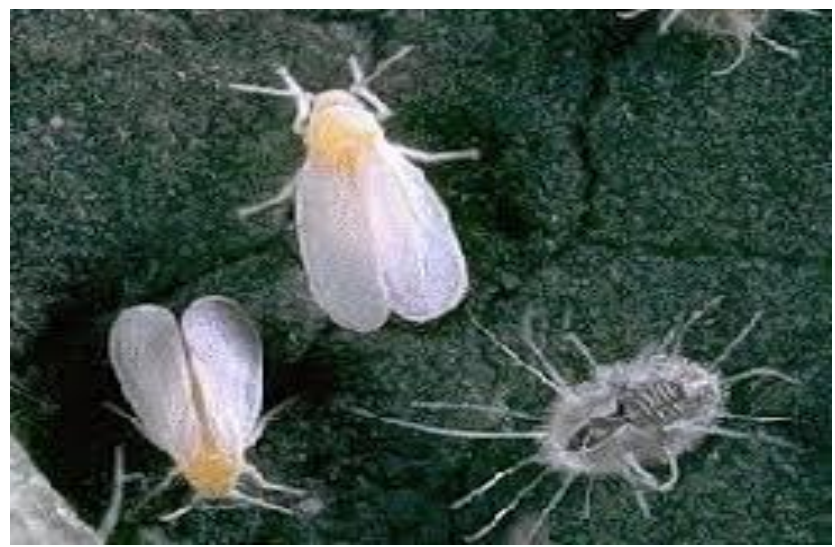

Fig. No 5. Whitefly Bemisia tabaci vector

Leaf curl is a widely recognized and damaging disease of the upland cotton within the Africa and in Indian subcontinent. Its ingenious mediator has been described from India, Pakistan and Sudan (Azhar et al., 2010). Whitefly Bemisia tabaci is 
transmitted by single-stranded satellite DNA $\beta$ portion and a small side impact directing, illness to be caused by a complex of monopartite begomoviruses (Akhtar et al., 2013). The begomovirus - beta satellite edifices that reason cotton leaf curl virus ailment in Africa and Asia are particular. Amidst of 1990s, the complex of different begomovirus species appeared in Pakistan and India (regularly contaminating every plant for one or more infection), and caused an illness in which particularly beta satellite (Cotton leaf curl Multan beta satellite [CLCuMuB]) was associated (Tahir et al., 2011). In 2001, intensity of infection of a begomovirus was increased and the existing strain defeated existing resistance which was generally accounted for in Pakistan (Akhtar et al., 2002; Mansoor et al., 2003). Reported that after studying the DNA sequences one comes to the conclusion that there was only one type of begomovirus that developed it to act as infectious agent (Tahir et al., 2011). In a huge number of Begomo viruses consisted of two genomic fragments known as DNA-A and DNA- $B$, which are required for illness that is spread by whitefly Bemisia tabaci (Monga et al., 2011).

Here is a large number from the ancient World which have as it were a single fragment comparable to DNA-A, which has been isolated and displayed to bring on illness indications (Navot et al., 1991; Dry et al., 1993). In Pakistan, the most important crop is cotton, over $60 \%$ cotton is exported to foreign contraries for earnings (Briddon et al., 2000). Cotton is major fiber crop in Pakistan and it only only share $1.2 \%$ in of its production in local market and rest of the amount is exported worldwide. Cotton leaf curl disease (CLCuD) could be a major risk to the production of cotton in Pakistan (Azam et al., 2013). CLCuD has particular symptoms in which swelling, blackening and thickening of veins, downward or upward rolling of leaves, and cognation (Akhtar et al., 2002).

The fibers of the cotton plant are single cells. An ovule epidermal cell on differentiation and growth produces a cotton fiber. When the cell is alive it elongates and has normal set of cellular structures. New growing fiber cell have only primary cell wall and continues to grow further up to 39 days and develops secondary cell wall at the $17^{\text {th }}$ day of its differentiation (Pesquet et al., 2011). On the deposition of secondary cell wall the thickness of the fiber increases. In cotton plant both primary and secondary cell walls are made up of cellulose. The deposition of the cell wall requires a unique set of enzymes with specific conditions. Cotton plant provides us an array of other textile products such as clothing, animal feed, oil and various other industrial products. As we can define species of virus and is all terms definitions can be devised but what is a virus and what is the entity it is still questionable (Van Regen mortel et al., 2006). We find different meanings of virus by different authors, it is a thing that different scientists understand by their experiments as they used to stay it causes infections in body and potentially very strong pathogenic parasite in living bodies. It is sometimes can be defined as a parasite that is small and obligate intracellular either it contains a DNA or RNA genome that is surrounded by a virus coded protein that is protective for it and structure of nucleoprotein is a type of nucleic acid as name has sowed us, it too contain either DNA or RNA (Roossinck et al., 2011).

This publication is licensed under Creative Commons Attribution CC BY.

http://dx.doi.org/10.29322/IJSRP.10.05.2020.p10156
Later on it was found that there are certain other genotypes; cotton leaf curl Multan virus (CLCuMuV), cotton leaf curl Burewala virus (CLCuBuV) and cotton leaf curl Kokhran virus (CLCuKV) cause CLCuV disease. Just one sort of DNA $\beta$ satellite, generally beginning from CLCuMuB DNA $\beta$ segregated from tomato, is observed to be related with the disease that was observed to be related but now clearly deficient with regards to an alpha satellite (Tahir et al., 2011).

As of late, CLCuBuV has been accounted for India and commanding in numerous crops (Kumar et al. 2011; Rajagopalan et al., 2012). These viruses are transferred to the plant by whitefly (Bemisia tabaci). Different pathogens, insects and pests cause various disorders in which cotton is infected (Khan and Ahmad, 2005). With the passage of time $\mathrm{CLCuV}$ has spread in all areas of Pakistan (Tariq, 2005). During the last decade, 9.45 million bales of cotton production decrease due to CLCuV virus (Hussain, 1995; Khan et al., 2001). For the textile sector, higher strength of fiber is very important. The high fiber strength does not have its availability in commercial kinds in Pakistan. For extra fiber strength starting Culp and Harrel (1973), Green and Culp (1990), and Culp and Green (1992) starting in 1946,focused on transferring genes, which was based on Beasley (1940) triple hybrid to develop cotton plant (Ahmad et al., 2010). If plants are infected early in their life, right after germination, and then the symptoms are more severe with no harvestable lint. On the other hand if the plant was infected very late in his life then the symptoms will be milder (Sattar et al., 2013).

The inverse relation between fiber strength and lint yield was terminated and fiber strength was increased. Mostly cotton produce in Punjab, Rajasthan, Haryana, Gujarat, Andhra Pradesh, Maharashtra states in India. Those all areas in which grow cotton are infected by whitefly-transmitted begomovirus. The primary record of CLCuD in India than Sri Ganganagar, Rajasthan in 1993 (Ajmera et al., 2004).

In 1978, a period of Gemini virus was noticed on distinctive plants with different features of size and structure and was at last demonstrated to be single stranded deoxyribonucleic acid virus (Mathews, 1987). During the year 1997 outburst of disease was recorded in all these three states and people were infected with the disease roughly about 2.19 lakh. Including biotic and abiotic stresses the environmental calamities are the major threats to food security and agriculture. A number of crucial plant diseases are due to biotic stresses including viruses and are liable for a large number of deficits of yield production and its nature in all segments of the world also in Pakistan. The family Gemini viridae comprises of three genera i.e. Mastrevirus, Curtovirus and Begomovirus. A well-known bad gather of these infections are related to sort Begomovirus, a source of great danger to cotton yield which is known to us as Cotton leaf curl infection malady (CLCuD) and is spreaded from one to another by whitefly i.e. Bemisia tabaci complex (including B. argentifolii) in a ceaseless way (Brown et al., 1995). There is a contaminated plant of cotton from which DNA is separated with CLCuD exposed a great ranging similarity with the Begomoviruses and other DNA-A fragments and Indian sub-continent (Zhou et al., 1998).

In Vidarbha region, the most crucial cash crop is cotton, raised on an area of 13.00 lacks hectors with of 27 lack cotton bales 
(2008-09). Decreasing in the output of the cotton is due to diseases. Most of the disease is present on cotton plant leaves about $80 \%$ to $90 \%$ (Azam et al., 2013). The point to ponder here is the cotton tree leaf rather than a complete cotton leaf plant is mainly borne from various infections like fungus, foliar leaf spot of cotton. Various negative impacts have been seen on the morphology of the infected plants and it has been seen that the disease have cancerous effect on the cotton filaments (Ahmad et al., 2002). Among the symptoms of cotton leave curl virus disease appearance of different colors on the leaves is an important one. To control the disease it is the most effect technique to pick up the infected leaves out from the rest of growing crop (Agrions, 1978).

According to the studies of Iqbal et al., (2006) Seed cotton production has some significant and positive relationship with sympodial per plant, bolls per plant and boll weight. (Kale et al., 2007). Infections are able to contaminate all sort of living beings including plants, creatures, microscopic organisms, and Archaea infections (Huang et al., 2010) are ubiquitously show in all biological systems around world (Edwards et al., 2005). In Pakistan, one within the India and other within the Sudan begomo infections having seven species detailed so distant while five out of seven have been recognized (Amin et al., 2006; Sharma and Rishi, 2007). A latest recombinant strain of A begomovirus derivative from cotton leaf curl Multan called (CLCuMV) and Kokhran virus (CLCuKV) has been found in existing cotton assortments with the breakage of resistance to be related with a latest recombinant strain (Akhtar et al., 2010). Cotton leaf curl Burewala virus (CLCuBV), having recombinant strain infection which is present in Pakistan whose commonly growing in cotton. One of the premium ways to conflict $\mathrm{CLCuV}$, especially all endeavors in which treatment have ineffectual and when there is high inoculum pressure by the assortment of breeding resistant.

Different attempts have been made to exchange resistant genes through interspecific hybridization between diploid and tetraploid species have been developed by cotton plant. Clear (1963) exchanged unaffected genes caused by Puccinia cacabata against cotton rust (Bao-Liang et al., 2003).

Qualities for resistance against illness and dry season have been exchanged among Gossypium hirsutum and Gossypium arboretum (Amin, 1940). Interspecific introgression has moreover been done during the Gossypium hirsutum and Gossypium arboretum. Essentially, safe qualities against bacterial curse of cotton display in G. Arboretum have been introgressed into G. Barba thick (2009) against Rotylenchulus reni shape is from $2 \mathrm{n}$ to $3 \mathrm{n}$ cotton (Knight, 1957; Brinkerhoff, 1970). Among the population of peoples in which the sum of genetic variability and genetic diversity can be characterized and the betterment of crop and also hereditary for supportability. It is a zone of interest. Gossypium arboreum L. has various promising characteristics such as dry season resilience and tolerate to insects, pests etc., which are not present in the G. hirsutum L (Mehetree et al., 2003). In any case, for the final two decades the cotton production has remained quiet in which both biotic and abiotic stresses containing a few components in which cotton has great yield quality and fourth biggest producer in Pakistan than others (Saeed et al., 2014). Cotton leaf curl disease (CLCuD) is one This publication is licensed under Creative Commons Attribution CC BY. and only the main restricting components producing vast crop damages (Farooq et al., 2011). Numerous efforts by creating resistance/tolerant variabilities using diverse conservative breeding approaches have been made by the breeders to overcome this issue but these assortments ended up helpless after two to three a long time due to changes happening within the viral strains causing CLCuD.

In this manner, appropriate genetic changeability, proper misuse of the polyploidy creation and presentation of misuse exotic germplasm are exceptionally critical and existing various varieties through hybridization (Ismail et al., 2008).

Different levels of chromosomal variety can be assessed utilizing different mathematical methods such as fundamental factors analysis (Li Zheng et al., 2008). Cluster examination and most important methods are organized (Brown et al., 2000). Among these biometrical strategies, the major prerequisite of central component in which study can be allocated in each genotypes as it were bunch only and it too imitates the importance of biggest supporter to full inconstancy in every point of separation (Sharma et al., 1998). The effect of cotton leaf curl virus $(\mathrm{CLCuV})$ which causes cotton leaf curl disease (CLCuD), on the expression of oxidative enzymes of cotton plants (Genus: Gossypium) has extensively been studied. Generally, this disorder prevails in many plants of the family malvaceae (Azhar et al., 2013). In the structure of leaves virus causes very unusual changes in the cotton plant such as the formations of outgrowths and enations on veins and the underside the leaf. The growing enations appear leaf-like and can be the size of the leaves on which they are present (Akhtar et al., 2000). The effects of this virus are very unusual, such as the plants infected with this virus have more amount of chlorophyll in their leaves than the normal plants. The distribution of chlorophyll is more in $\mathrm{CLCuV}$ infected plants however based on the age and certain other morphological features of the plant; hence symptoms may vary accordingly (Sattar et al., 2013).

Application of pesticide have very harmful impacts caused on the environment in which whitefly may cultivate the resistance of pesticide (Pico et al., 1998; Palumbo et al., 2001). The foremost important aspect of control of illness is utilization and documentation of solid sources of plant resistance. The use of it is simple, very effective and environmentally friendly as compared to depending on pesticides. From the past 20 years, many influential steps have been taken to produce CLCuD-resistant cultivars in Pakistan. As the time passed, the infection was strongly manage by producing CLCuD-resistant variety. As of late, a strain of the infection that overcame this resistance appeared and rendered already different safe assortments susceptible (Akhtar et al., 2008).This consider was started to recognize sources of resistance in developed and wild genotypes indicating five Gossypium species. Many present researches have an objective to explore the genetic potential of different cotton cultivars and relation of seed cotton generation with different precedence, production and fiber related traits under CLCuV serious states.

\section{MATERIAL AND METHODS}

\section{Plant material}


Eight cotton cultivars, each with two replications with known $\mathrm{CLCuV}$-resistance and vulnerability levels were taken and grown in green house.

\section{Source of viral inoculums}

A susceptible inoculated cotton plant was serving as a source of $\mathrm{CLCuV}$ source. These plants are inoculated artificially which were put in their favorable environment in the green house (Akhtar et al., 2013).

\section{Virus transmission and identification}

Newly growing cotton plants were inoculated with the virus strain $(\mathrm{CLCuV})$. Data were recorded on the ratio of effective grafts, rate of illness transmission, inactive sum (aver-age time needed for initial symptom look once grafting), and sort of indications created ninety days post vaccination (Akhtar et al., 2015).

\section{Total soluble protein content}

Mature leaves were used for extraction of protein contents by grinding them in extraction tube. Involvement of protein components in plant infections resistance has been reported in numerous plant pathogenic intuitive (Tornero et al., 2002; Carballo et al., 2006). In non-inoculated plants, total soluble protein substances was essentially higher in leaves of vulnerable genotype-I but was comparative in vulnerable genotypes-II and both of the resistant genotypes. As a rule contaminated, plants appear high protein content, which could be due to both the activation of the host defense mechanisms and the pathogen attack components (Agrios, 1997). The high level of susceptibility of these genotypes in which possible explanation for significant decrease in total soluble proteins in susceptible genotypes after $\mathrm{CLCu}-\mathrm{BuV}$ injected. Comparative results have been detailed in maize, tomato, grapevine, and apple contaminated with mollicutes (Favali et al., 2001; Bertamini et al., 2002, 2002; Musetti et al., 2010).

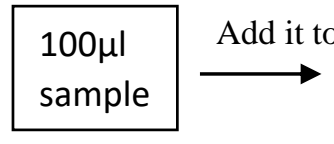

Charge it into

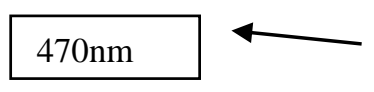

Take absorbance at

Fig. No 6: Flow chart of peroxidase activity

\section{Peroxidase (POD)}

POD estimation was done with the help of potassium phosphate buffer, $100 \mu 1$ reaction mixture, and $100 \mu 1$ samples. The reaction was initiated by adding the enzyme extract. At $470 \mathrm{~nm}$ increased the absorbance of the reaction solution after every 20s was recorded. POD activities were recorded based on the definition that one unit of activity of POD is 0.01 unit per minute of rate of change of absorbance (Gogai et al., 2011).

\section{(2, 2-diphenyl-1-picryl-hydrazyl-hydrate (DPPH) Activity}

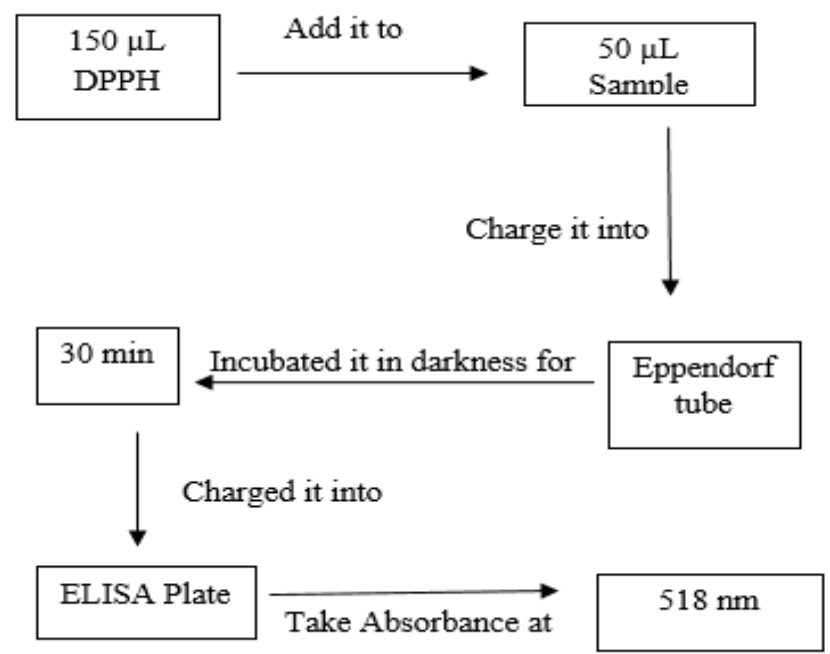

Fig. no 7: Flow chart of DPPH activity

Sample stock solution in which $150 \mathrm{ul}$ DPPH added it to $50 \mu \mathrm{l}$ sample were diluted to final concentrations then charge it into Eppendorf tube. After the mixtures were vigorously shaken they were incubated in dark for $30 \mathrm{~min}$ after incubation again charged it into ELISA plate in which different values of sample solutions, and then take at room emperature for 30 mints the absorbance values were measured after $30 \mathrm{mins}$ were recorded at $518 \mathrm{~nm}$ and change over into the rate antioxidant activity (AA) utilizing the following formula: A 100 = Abs sample-Abs blank /100Abs control

They must take blank absorbance in which we take Ethanol $(150 \mathrm{~mL})$ plus plant extract solution $(50 \mathrm{~mL})$. For negative control DPPH solution was used and the standard solutions using the positive controls.

\section{Total Flavonoid Content}

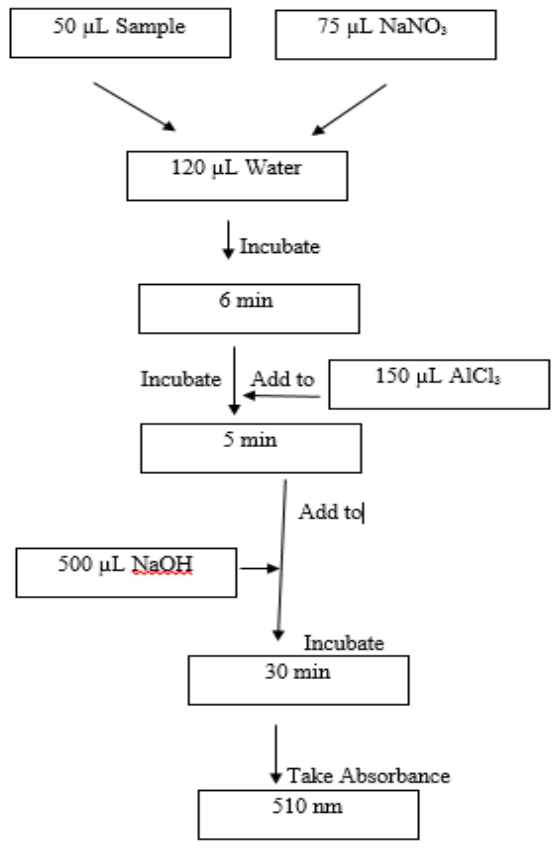

Fig. No: 8 Flow chart of Total flavonoid content 
Aluminum chloride colorimetric assay was used to measure by total flavonoid contents. An adding $50 \mu \mathrm{l}$ sample of extract and $75 \mu \mathrm{l} \mathrm{NaNO} 3$ was put to $10 \mathrm{ml}$ flask having $120 \mu \mathrm{l}$ of distilled water then incubate for 6 minutes. After 6 minutes, $150 \mu \mathrm{A} \mathrm{AlCl}{ }_{3}$ was added than incubate for $5 \mathrm{~min}$. After incubation we were added, $500 \mu \mathrm{l} \mathrm{NaOH}$ and the total concentrations was made up to $10 \mathrm{ml}$ with distilled water than incubate for $30 \mathrm{~min}$ and in the last step absorbance was taken by ELISA reader at $510 \mathrm{~nm}$. Through this method a blank sample was also run (Georgleva et al., 2011).

\section{Total protein content}

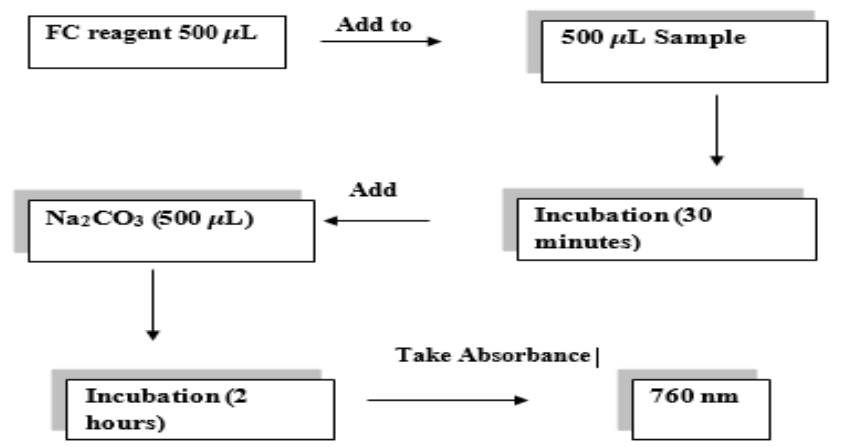

Fig. No 9: Flow chart of total protein content.

Protein content of 8 samples ( $500 \mu$ l each) was determined by above mentioned protocol. A blank sample was also run through this procedure as a control.

According to the literature total phenolic contents were determined (Singleton \& Rossi, 1965. Added $500 \mathrm{~mL}$ of the diluted sample into diluted Folin- Ciocalteu reagent (the most common usage of FC reagent for determining protein concentrations in Lowry method) then incubation for 30 minutes. After $30 \mathrm{~min}$, we were added $500 \mu \mathrm{l}$ of saturated sodium carbonate solution. The mixture absorbance was measured at $760 \mathrm{~nm}$ after incubation for 2 hours at room temperature. At the end absorbance was taken by ELISA reader (Song et al., 2010).

\section{Catalase (CAT)}
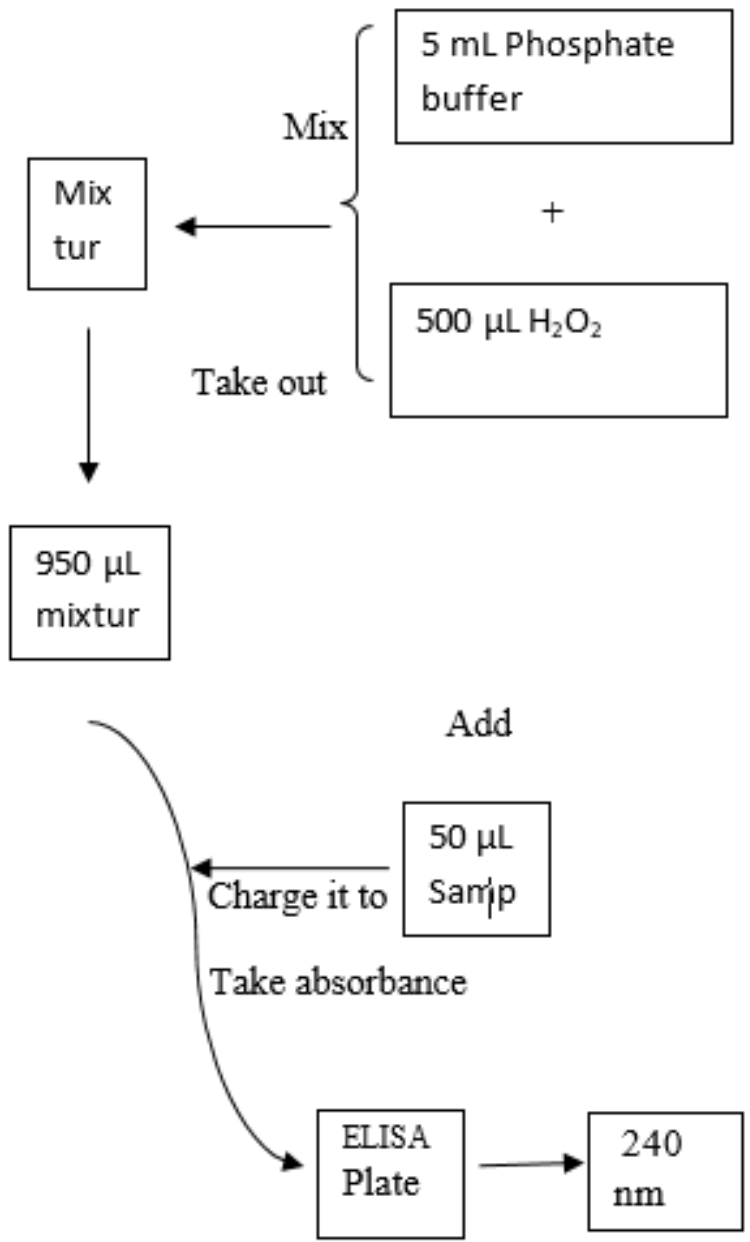

Fig. No 10: Flow chart of catalase activity.

Catalase activity was by $5 \mathrm{ml}$ potassium phosphate and $500 \mathrm{ul}$ water for some modification of CAT action. Extract from both $\mathrm{CLCuV}$-inoculated and non-inoculated plants were completely blended in a medium composed of $50 \mathrm{mM}$

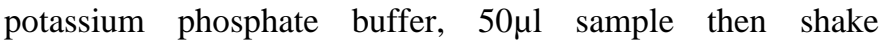
vigorously at $\mathrm{pH} 7.0$ for measurement of CAT activity. The absorbance was recorded at $240 \mathrm{~nm}$ after every $20 \mathrm{~s}$ and reduction in reaction solution. CAT activity were recorded based on the definition that one unit of activity of CAT is 0.01 units'min-1 of rate of change of absorbance. And enzyme activity was expressed on the base of fresh weight (Hameed et al., 2011).

\section{Protease activity}

Protease activity was obtained from CLCuV inoculated and non- inoculated plants, treated with potassium phosphate buffer solution of casein and TCA solution. Enzyme activity was done by ELISA reader. To all the tubes, $100 \mu \mathrm{l}$ of protease extracts was added and mixed well. A blank sample was also run through this method. Exactly after 10 min added 
sample, reaction was stopped. 2.0 $\mathrm{ml}$ TCA solution and mixed well. Tubes were then allowed to stand for $10 \mathrm{~min}$, and then reaction solution was filtered to remove the precipitate formed during reaction. The filtrate absorbance was measured at 280 $\mathrm{nm}$. By this method, protease activities were recorded based on the definition that one unit of activity of protease is 0.001 unit per minute is that amount of enzyme, A280 per min at $37^{\circ} \mathrm{C}$ and $\mathrm{pH} 7.8$. On protein basis enzyme activity was also expressed (Hameed et al., 2013).

\section{Superoxide dismutase (SOD)}

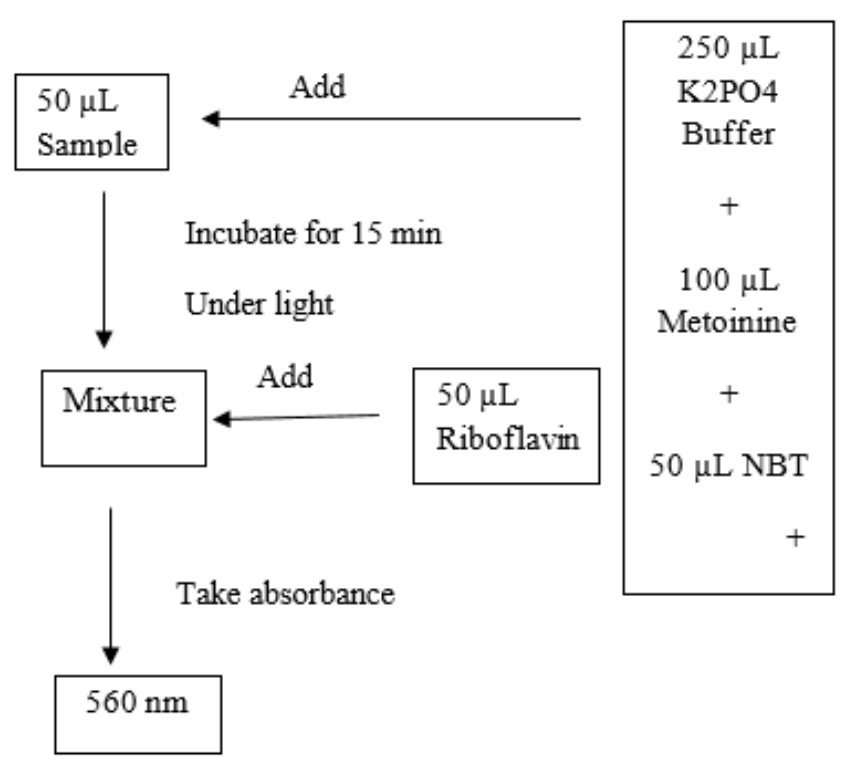

Fig. No 11: Flow chart of Superoxide dismutase (SOD)

Leaves extracts of CLCuV cotton plants were tested with 50 $\mu \mathrm{l}$ sample and 250 potassium phosphate buffer, $100 \mu \mathrm{l}$ methionine, $100 \mu \mathrm{l}$ Triton $\mathrm{X}, 50 \mu \mathrm{l}$ NBT ,400 $\mu \mathrm{l}$ distilled water all are charged into Eppendorf then take under light for 15 min and take out and add $50 \mu \mathrm{l}$ Riboflavin and then take absorbance at 560nm. While nitro blue tetrazolium (NBT) will be reduced photo chemically (Dixit et al., 2001).

For the assessment of SOD activity, leaflet was homogenized in a medium solution composed of $50 \mathrm{mM}$ potassium phosphate buffer. To inhibit the photochemical reduction of nitro blue tetrazolium (NBT) and measuring its ability and the activity of SOD was assayed. One unit of activity of SOD was determined which caused $50 \%$ inhibition of photochemical reduction of NBT due to the quantity of enzymes.

\section{* RESULTS AND DISCUSSION}

\section{CLCuV cotton plant}

Disease response

$\mathrm{CLCuV}$ inoculated plants of all tested genotype showed a wide range of symptoms depending on their genetic makeup. From $G$. hirsutum developed disease symptoms 10 days post inoculation and showed sever symptoms like leaf rolling \& curling, swelling and darkening of veins, and leaf-like outgrowths called 'enations' within 30 days post inoculation of susceptible genotypes. All the grafting inoculated plants of

This publication is licensed under Creative Commons Attribution CC BY. http://dx.doi.org/10.29322/IJSRP.10.05.2020.p10156 resistant genotypes from $G$. herbaceum (Co Tiep Khac) initiated disease at 30 days post inoculation, respectively.

On these genotypes CLCuD symptoms started as slightly vein swelling/darkening and 'enations'on the veins on the undersides of leaves and G. herbaceum (Co Tiep Khac) leaves of the grafted plants on few symptoms were developed. The end of the experiment ( 90 days post inoculation) no disease severity was observed. Through PCR CLCuBuV was readily detected in both symptomatic and symptom-less leaves of these plants. The lower disease severity in the leaves of $\mathrm{CLCuBuV}$-inoculated plants of genotypes and ( $G$. herbaceum) (Akhter et al., 2013). . Involvement of protein components in plant infections resistance has been reported in numerous plant pathogenic intuitive (Tornero et al., 2002; Carballo et al., 2006). In non-inoculated plants, total soluble protein substances was essentially higher in leaves of vulnerable genotype-I but was comparative in vulnerable genotypes-II and both of the resistant genotypes. As a rule contaminated, plants appear high protein content, which could be due to both the activation of the host defense mechanisms and the pathogen attack components (Agrios, 1997). The high level of susceptibility of these genotypes in which possible explanation for significant decrease in total soluble proteins in susceptible genotypes after $\mathrm{CLCu}-\mathrm{BuV}$ injected. Comparative results have been detailed in maize, tomato, grapevine, and apple contaminated with mollicutes (Favali et al., 2001; Bertamini et al., 2002, 2002; Musetti et al., 2010).

The present study indicated that the two enzymes (SOD and POD) reacted in the same way to the disease (a decline of their activities with the disease aggravation) which may be explained by their co-regulation. Previous studies also reported the simultaneous induction or decline of the two enzymes (Shigeoka et al., 2002; Abedi and Pakniyat 2010) .

The CAT activity was found to be positively correlated with the disease thus negatively correlated with the resistance. The increase of the CAT can be explained by the decline of the POD activity leading to an increase of hydrogen peroxide which must be scavenged by the CAT. CAT is enzymes with the potential to directly dismutase hydrogen peroxide into $\mathrm{H}_{2} \mathrm{O}$ and $\mathrm{O}_{2}$. They play an important role in the plant cells detoxification during oxidative stress. The level of CAT has been shown to increase in varieties sensitive to a stress (sarvista et al., 2002).

One of the main effects of $\mathrm{CLCuV}$ disease is the restriction of the water movement due the vessels occlusion in the infected plants. An important adaptation of plants to water stress is the increase in the concentration of intracellular solutes, such as proline and total soluble sugars (TSS), which facilitate the maintenance of cell pressure potential (Osakabe et al., 2014). The level of TSS was found to increase with the aggravation of the disease most probably due to the mentioned reason. Similarly the TSS show a significant buildup in leaves of inoculated paper plants from 20day (Osakabe et al., 2014) which tends to confirm our results. The proline content was not significantly correlated with the disease parameters in our study although it was reported to increase in infected plant in most of the reports (Siddique et al., 2014). Again in this study, the lack of correlation can be explained by the different level of the disease. In our study the augmentation of the protein 
content is positively correlated with the disease; this fact can be explained by the activation of the host defense mechanism and the pathogen attack mechanism which both required the production of new proteins (Siddique et al., 2014).

In the field, only three parameters were tested for two years experiments: one antioxidant enzyme (SOD) and the content of proline and total soluble sugar. The correlation of the biochemical parameters with the disease parameters differed in the two years. The 2015 SOD activity was not correlated with any of the same year disease parameter however, in 2014, a correlation was observed between the disease incidence and the SOD activity. The TSS content had shown a negative correlation with the two disease parameters in 2014 but was only positively correlated with the disease incidence in 2015. The proline content had shown a negative correlation with the disease index in 2014. These observed variations of the SOD activity and in the content of TSS and proline can be explained either by the difference level of reactivity of our population lines to the disease from year to year, the instability of the environmental conditions and the level of virulence of the pathogens present in the field. The decrease of the total soluble sugar with the aggravation of the disease observed in 2014 can be explained by the use of the total soluble sugars to maintain the cell pressure potential.

In any case, protein substance was found to be diminished essentially in CLCuBuV-inoculated plants of both susceptible genotypes (CIM-496, 20.39\% and NIAB-111, 23.64\%), whereas it was found to alter non-significantly in leaves of vaccinated plants of both resistant genotypes Ravi $(9.41 \%)$ and Co Tiep Khac (11.04\%), as compared to their noninoculated plants. In this study, aside the negative correlation between SOD and CAT and the SOD and the POD, no other correlation was observed between the antioxidant enzymes. However moderate correlations were found between antioxidant enzymes and the other biochemical compounds. In a study on tomato's antioxidant response to salt stress (Frary et al., 2010).

Another interesting remark is that except for one trait (TSS), no correlation was obtained between the trait measured in the greenhouse and those measured in the field. This lack of correlation can be explained by the non-controlled environment in the field (other diseases, drought, and insects).

\section{Levels of POD in Cotton Plant}

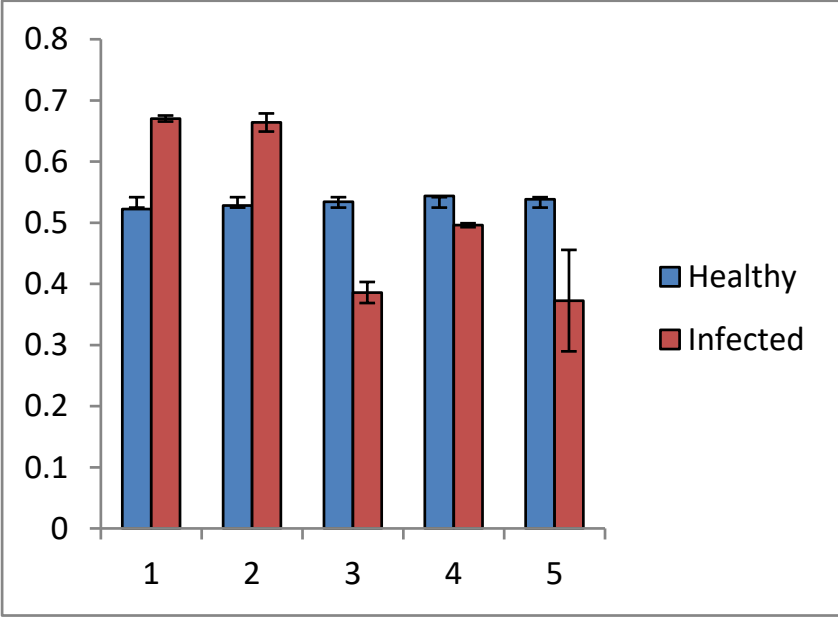

This publication is licensed under Creative Commons Attribution CC BY. http://dx.doi.org/10.29322/IJSRP.10.05.2020.p10156
Fig. No.12: Levels of peroxidase enzyme in cotton plant (cotton leaf curl virus) under biotic stress, showing that the expression of POD in two of the infected samples got over expressed and rest of the 3 out of 5 got suppressed.

Peroxidase is an enzyme during a wide selection of organisms, from plants to human to bacterium. Its major function is to breakdown peroxide that is one in every of the toxins produced as a byproduct of using oxygen for respiration. It is a chemical compound and antioxidant resistant. Expression of levels is checked in IU/ml of protein.

Peroxides are also one of the primary responding enzymes giving quick defense against plant pathogens. As reported by Siddique et al., 2014,resistance against pathogens and in the regulation of the cell wall elongation wound healing they are involved (Zhou et al.,2012).

Cotton leaf curl virus is not a seed borne disease while it is transmitted by the Whitefly Bemisia tabaci and some virus lives in alternate hosts. After infection of three plants with cotton leaf curl virus expression of peroxidase enzyme was studied in terms of enzyme activity. The expression levels of peroxidase are measured in IU/ml. In first two infected cotton plant, graph shows that there are higher expression of POD in infected plant than healthy plants. The rest of three plants are showing lower expression of POD in infected plants. Expression levels of peroxidase in which results were significant $(1.352 \pm 0.548),(2.971 \pm 1.18)$ and $(0.969 \pm 0.387)$ were recorded with extract. So, predominantly the infection causes the suppression POD expression as the graph suggests the value of POD activity of $1.337 \pm 0.538$ and $0.6703 \pm 0.017$ for healthy plants.

In non-inoculated plants POD activity was significantly higher of both susceptible genotypes, as compared to resistant genotypes plants was observed in NIAB-111 followed by CIM-496, Ravi, and Co Tiep Khac in which highest POD activity was non- inoculated. POD activity significantly decreased in CLCuBuV-inoculated plants of susceptible genotypes CIM-496 (31.54 \%) and NIAB-111 (26.497\%) compared to the non-immunized plants, whereas it changed none essentially in $\mathrm{CLCuBuV}$-inoculated takes off of both resistant genotypes (Mydlarz \& Harvell 2006).

\section{Levels of CAT in Cotton Plant}




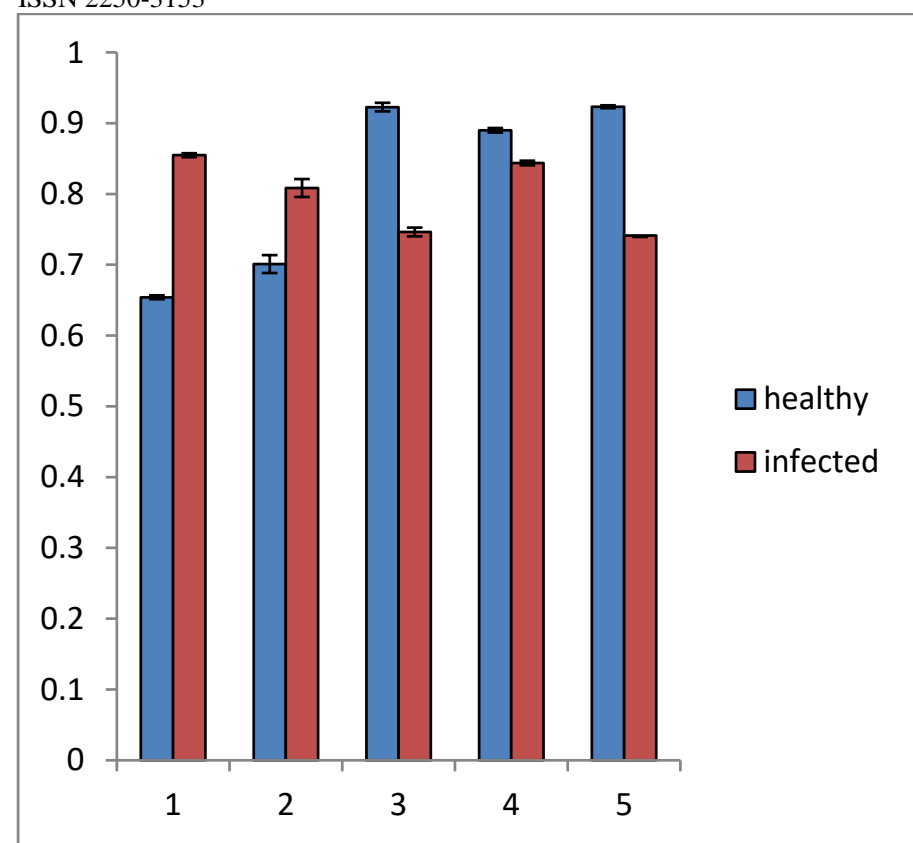

Fig. No.13: Levels of catalase (CAT) in cotton plant (cotton leaf curl virus $\mathrm{CLCuV}$ ) under biotic stress, showing that the expression of CAT in two of the infected samples got over expressed and rest of the 3 out of 5 got suppressed.

$$
2 \mathrm{H}_{2} \mathrm{O} \longrightarrow 2 \mathrm{H}_{2} \mathrm{O}+\mathrm{O}_{2}
$$

It is also measured in international unit (IU/ml) of protein. Cotton leaf curl virus is not a seed borne disease while it is transmitted by the Whitefly Bemisia tabaci and some virus lives in alternate hosts. After infection of five plants with cotton leaf curl virus, the expression of catalase enzyme was studied in terms of enzyme activity these cotton plants graph shows that 2 plants are having higher activities for catalase on infection while the activities of catalase for 3 of these plants were suppressed. The expression levels of CAT are measured in IU $/ \mathrm{ml}$. It has been observed that expression levels of CAT $(8.312 \pm 0.058)$ of this group were dominantly suppressed by infection than the healthy plants $(8.226 \pm 0.0031)$. The effect of cotton leaf curl virus, $(\mathrm{CLCuV})$ which causes cotton leaf curl disease, (CLCuD) on the expression of oxidative enzymes of cotton plants. The results were significant as expression levels of catalyze (8.586 \pm 0.006$),(7.556 \pm 0.0021)$ and $(1.764 \pm 0.121)$ were recorded with extract. The CAT activity was found to be positively correlated with the disease thus negatively correlated with the resistance. The increase of the CAT can be explained by the decline of the POD activity leading to an increase of hydrogen peroxide which must be scavenged by the CAT. CAT is enzymes with the potential to directly dismutase hydrogen peroxide into $\mathrm{H}_{2} \mathrm{O}$ and $\mathrm{O}_{2}$. They play an important role in the plant cells detoxification during oxidative stress. The level of CAT has been shown to increase in varieties sensitive to a stress (sarvista et al., 2002).

\section{LEVELS OF (SOD) IN COTTON PLANTS}

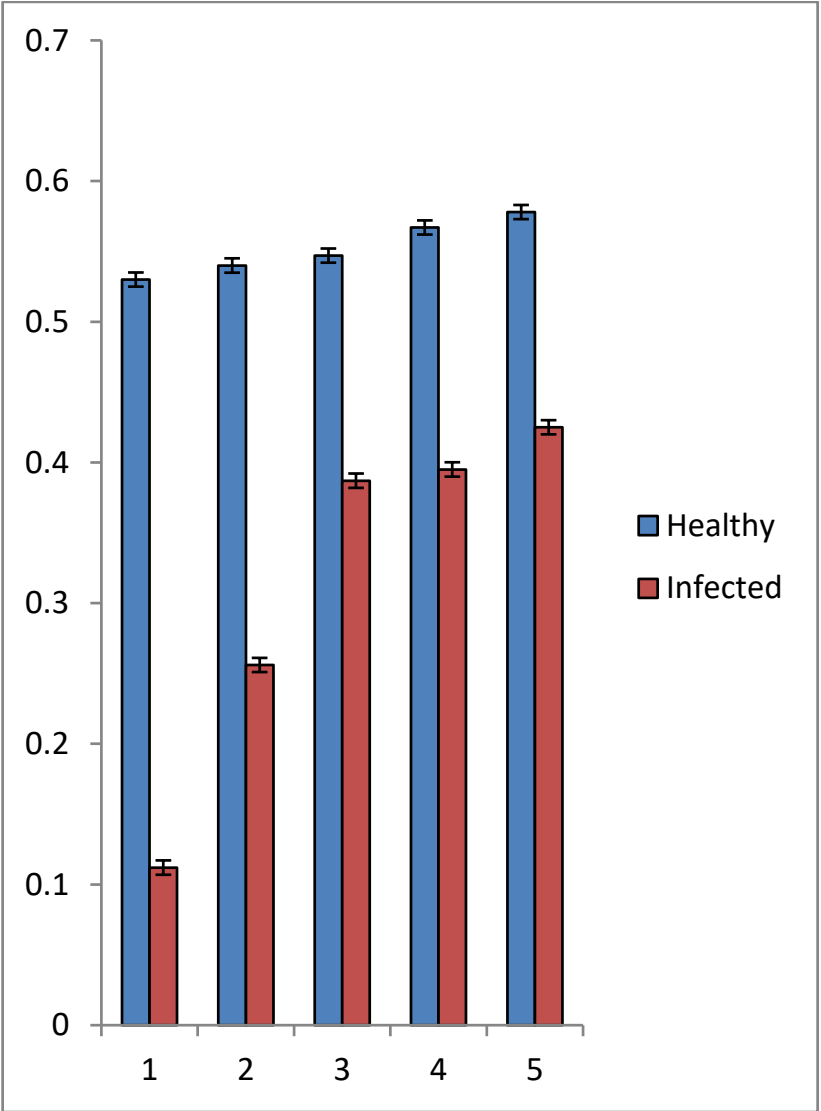

reported to increase in resistant cultivars with the resistance (Kumari et al., 2015). The results were significant as expression levels of sodium oxide dismutase (19.54 0.005$)$, $(0.664 \pm 0.082)$ and $(0.385 \pm 0.006)$ of protein were recorded with extract.

\section{LEVELS OF TOTAL PHENOLIC CONTENTS}

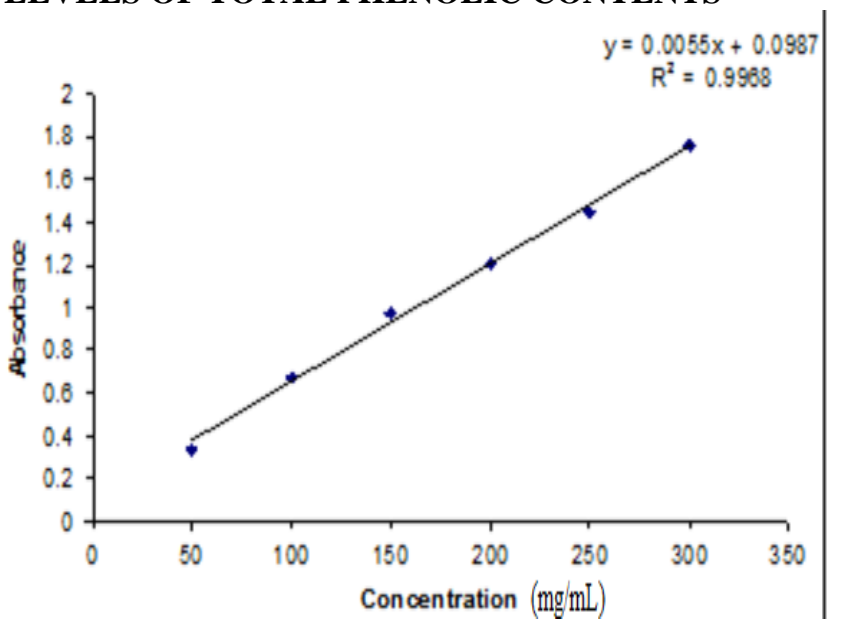

Fig. No.15: Graph shows that there is a strong linear correlation between absorption and concentration of phenolic contents over the defined limit of concentration. So based on the value of absorbance we can easily calculate the concentration at any other value of absorbance. 


\section{LEVELS OF TOTAL PHENOLIC CONTENTS IN PLANTS COTTON LEAF CURL VIRUS (CLCuV) UNDER BIOTIC STRESS}

The total phenolic contents can be measured using the Folinciocalteu reaction. In which results are typically expressed as Gallic acid equivalents. Cotton leaf curl virus is not a seed borne disease while it is transmitted by the Whitefly bemisia tabaci and some virus lives in alternate hosts. After infection of three plants with cotton leaf curl virus expression of total phenolic contents was studied in terms of enzyme activity in first infected cotton plant graph shows are higher expression in healthy plants. The expression levels of TPC are measured in $\mathrm{mg}$ of $\mathrm{GA} / \mathrm{g}$ of extract. It has been observed that expression levels of total phenolic contents $(60.43 \pm 1.346)$ of this group were much higher than the infected $(28.85 \pm 1.449)$ group. The effect of $(\mathrm{CLCuV})$ which causes cotton leaf curl disease, $(\mathrm{CLCuD})$ on the expression of oxidative enzymes of cotton plants.

The results were significant as expression levels of total phenolic contents $(15.59 \pm 2.021), \quad(20.023 \pm 1.008)$, $(32.21 \pm 1.361)$ of protein were recorded with extract.

\section{LEVELS OF TOTAL FLAVONOID CONTENT (TFC)}

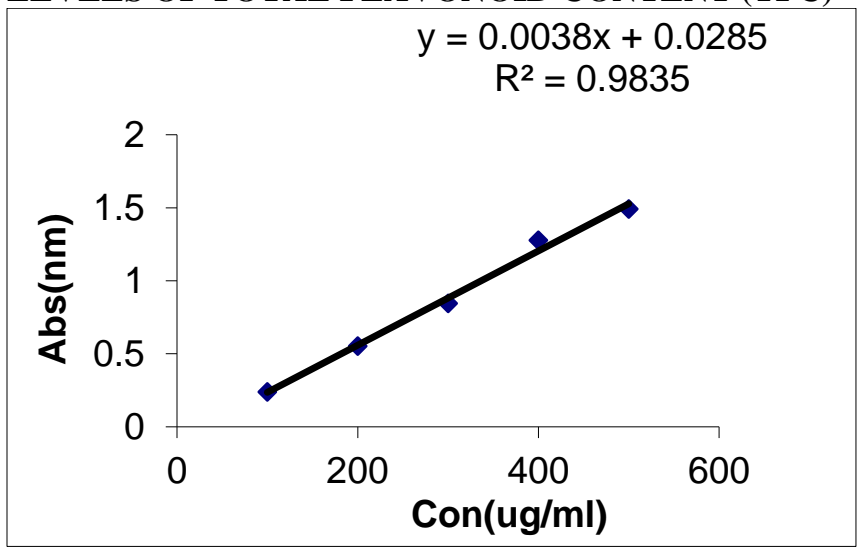

Fig. No.16: Graph shows that there is a strong linear correlation between absorption and concentration of flavonoid contents over the defined limit of concentration. So based on the value of absorbance we can easily calculate the concentration at any other value of absorbance.

The standard curve equation: $\mathrm{Y}=0.038 \mathrm{x}-0.0285$ with $\mathrm{r}^{2}=0.9835$. The total flavonoid content was calculated from a calibration curve, and the result was expressed as $\mathrm{mg}$ equivalent per gram dry weight.

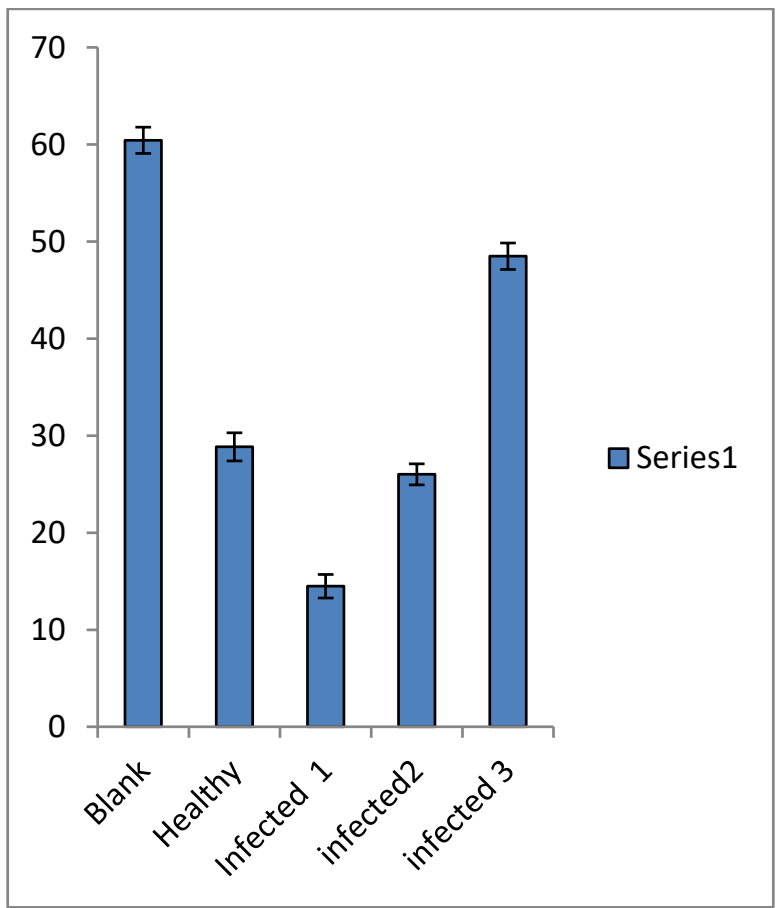

Fig. No.17: Levels of (TFC) In Plant (Cotton Leaf Curl Virus) Under Biotic Stress. This graph shows that TFC in two out of three infected plants got decreased and one of the infected plants showed higher level of TFC as compared to the healthy plant.

The total flavonoid content of fluid extract as determined by the aluminum chloride colorimetric method .The total flavonoid content was calculated from a calibration curve, and the result was expressed as mg rutin equivalent per g dry weight. Cotton leaf curl virus is not a seed borne disease while it is transmitted by the Whitefly bemisia tabaci and some virus lives in alternate hosts. After infection of three plants with cotton leaf curl virus expression of total flavonoid contents was studied in terms of enzyme activity in first infected cotton plant graph shows are higher expression than healthy plants. The expression levels of total flavonoid contents are measured in $\mathrm{mg}$ ruitn per day. It has been observed that expression levels of TFC (28.8 \pm 1.449$)$ of this healthy group were much higher than the infected $(14.48 \pm 1.203)$ group. The effect of cotton leaf curl virus, (CLCuV) which causes cotton leaf curl disease, $(\mathrm{CLCuD})$ on the expression of oxidative enzymes of cotton plants.

The results were significant as expression levels of total flavonoid contents $(26.013 \pm 1.008),(48.43 \pm 1.361)$ and $(32.42 \pm 1.563)$ of protein were recorded with extract.

\section{LEVELS OF (DPPH) IN COTTON PLANT}

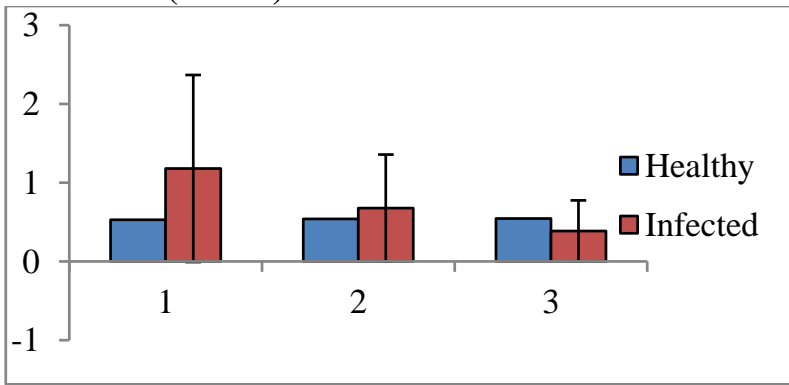


Fig. No.18: Graph of Levels of (DPPH) In Cotton Plant (Cotton Leaf Curl Virus) Under Biotic Stress shows that the level of DPPH in two out of three infected samples got suppressed and one of them showed enhanced level of DPPH after infection.

Cotton leaf curl virus is not a seed borne disease while it is transmitted by the Whitefly Bemisia tabaci and some virus lives in alternate hosts. After infection of three plants with cotton leaf curl virus expression of DPPH was studied in terms of enzyme activity in first infected cotton plant graph shows are higher expression than healthy plants. The expression levels of DPPH are measured in Iu. It has been observed that expression levels of DPPH $(7.303 \pm 0.25)$ of this group were much higher than the infected $(4.123 \pm 1.02)$ group.

The results were significant as expression levels of DPPH $(6.023 \pm 2.22),(4.502 \pm 0.09)$ and $(5.023 \pm 2.04)$ of protein were recorded with extract cotton leaf curl virus.

Table No.2: Levels of different parameters in expression of oxidative enzymes in cotton plant under biotic str

\begin{tabular}{|l|l|l|l|}
\hline Groups & POD & SOD & TFC \\
\hline $\begin{array}{l}\text { Healthy } \\
1\end{array}$ & $1.337 \pm 0.538$ & $25.54 \pm 0.0049$ & $28.85 \pm 1.449$ \\
\hline $\begin{array}{l}\text { Healthy } \\
2\end{array}$ & $1.352 \pm 0.548$ & $30.12 \pm 0.0147$ & $32.45 \pm 1.563$ \\
\hline $\begin{array}{l}\text { Infected } \\
1\end{array}$ & $2.971 \pm 1.188$ & $0.6703 \pm 0.017$ & $14.48 \pm 1.203$ \\
\hline $\begin{array}{l}\text { Infected } \\
2\end{array}$ & $1.697 \pm 0.678$ & $0.664 \pm 0.082$ & $26.013 \pm 1.088$ \\
\hline $\begin{array}{l}\text { Infected } \\
3\end{array}$ & $0.969 \pm 0.387$ & $0.385 \pm 0.006$ & $48.43 \pm 1.361$ \\
\hline
\end{tabular}

POD for Peroxidase, SOD for Superoxide dismutase, and TPC for Total protein content.

\section{Statistical analysis}

Statistical analysis was done by ANOVA along with Tukey's HSD (Honestly Significant Differences) test for all collected information. In triplicate manner all experiments were accomplished .Mean, standard deviation (SD) is used for the results and all the results are written according to this. For comparison between two means we used Student's t-test and if we wanted comparison of more than two means and one-way analysis of variance (ANOVA) was used (Runyon and Haber, 1988).

\section{Conclusion}

Important characteristics of plant resistivity to pathogens are from early and heavy levels of explaining different shield proteins .We need resistance for disease against $\mathrm{CLCuBuV}$ and many studies have explained those proteases. SOD, TFC POX, CAT, Protein, TFC and phenolic compounds play active part in its resistance. Exposed kinds after polluting with $\mathrm{CLCuBuV}$ and proteases, total phenolic and SOD were found to vary considerably in resistant due to the presence of high level of phenolic pre-infection and post-infection happens and additional studies are subjected to characterized the phenolic compounds and proteases involved and post-infection significant increase in resist squash yellow blotch tent cultivar Ravi may have further role in disease resistance.

\section{References}

Abedi, T., Pakniyat, H., (2010). Antioxidant enzymes changes in response to drought stress in ten cultivars of oilseed rape (Brassica napus L.) J. Gen. Pl BR, 46(1), 27-34.

Agrios, G.N. (1997). Plant Pathology. Academic Press, New York, USA.

Ahmad, S., K. Mahmood, M. Hanif, W. Nazeer, W. Malik, A. Qayyum, K. Hanif and A. Mahmood.2011. Introgression of cotton leaf curls virus-resistant genes from Asiatic cotton (Gossypium arboretum) into upland cotton (G. hirsutum).J. mol. gen. 10: 24042414.

Ahmad, G., S.A. Malik, Z. Mahmood, M .Z. Iqbal and S. Ahmad. 2002. Effect of cotton leaf curl virus disease on morphology, yield and fiber on susceptible lines/cultivars of cotton (Gossypium hirsutum L.)Asian J. Plant Sci.1: 705-707.

Ajmera, B.D.2004. National Seminar on Cotton Production

Challenges. Hisar, India.

Akhtar, K. 2010. Evaluation of Gossypium species for resistance to cotton leaf curl Burewala virus. ANN APPL BIOL. 157: 135-147.

Akhtar, K.P, R. Ulla, I.A. Khan, M. Saeed, N. Sarwar and Mansoor S.2013. First symptomatic evidence of infection of Gossypium arboretum with cotton leaf curls Burewala virus through grafting. IJAB.15:157160.

Akhtar, K.P., A. I. Khan, M. Hussain and M .S. I. Khan. 2002. Comparison of resistance level to cotton leaf curl virus ( $\mathrm{CLCuV})$ among newly developed cotton mutants and commercial cultivars. J. Plant Pathol. 18:179-186

Akhtar, K. P., Hussain, M., Khan, A. I., \& Khan, M. S. I. (2000). Screening of cotton mutants for the resistance against cotton leaf curl virus (CLCuV). Pakistan J. Biol. Sci, 3, 91-94.

Akhtar, K.P., F.F. Jamil, M.A. Haq, I.A. Khan. 2008. Comparison of resistance to cotton leaf curls disease (Multan/Burewala) among Gossypium hirsutumL. Varieties and breeding lines. J. Phytopathol. 156:352-357.

Akhtar, K.P, R. Ulla, I.A. Khan, M. Saeed, N. Sarwar and Mansoor S.2013. First symptomatic evidence of infection of Gossypium arboretum with cotton leaf curls Burewala virus through grafting. Int. J. Agric. Biology. 15:157-160.

Akhtar, K. P., Hussain, M., Mahmood-Ul-Hassan, M. S., \& Sarwar, N. (2015). Evaluation of Bt-cotton genotypes for resistance to cotton leaf curl disease under high inoculum pressure in the field and using graft inoculation in glasshouse. The plant pathology journal, 31(2), 132. 
Amin, K. C. (1940). Interspecific hybridization between Asiatic and new world cottons. Ind. J. Agric. Sci., 10, 404-13.

Amrao, L., I .Amin, M.S. Shahid, M.S. Briddon, R.W. Mansoor. 2010. Cotton leaf curl disease in resistant cotton is associated with a single Begomovirus that lacks an intact transcriptional activator protein. 152:153-163.

Azhar, M. T., Aftab, S., Zafar, Y. U. S. U. F., \& Mansoor, S. H. A. H. I. D. (2010). Utilization of natural and genetically-engineered sources in Gossypium hirsutum for the development of tolerance against cotton leaf curl disease and fiber characteristics. Int. J. Agric. Biol., 12, 744-748.

Azam, S., T. Samiullah, R. Yasmeen, A. Din, S. Iqbal, A. Rao, A. Q. 2013. Dissemination of BT cotton in cotton growing belt of Pakistan.

Azhar, M., Anjum, Z., \& Mansoor, S. (2013). Gossypium gossypioides: A source of resistance against cotton leaf curl disease among D genome diploid cotton species. J. Anim. Pl. Sci., 23(5), 1436-1440.

Bota, J. H., J. Medrano. 2004. Is photosynthesis limited by decreased Rubisco activity and RuBP content under progressive water stress? J. Phytol. 162:671-681.

Briddon, R. W. and P. G. Markham. 2000. Cotton leaf curls virus disease. 71: 151-159.

Brown, J. K., D.R. Froehlich and R.C. Rosell .1995. The sweet potato or silver leaf whitefly; biotype of Bemisia tabaci or a species complex. J. Entomol. 40: 511-53.

Boa-Liang, Z., S. Chen, S. Xin-Lian, Z. Xiang-Gui. 2004. Studies on the hybrid of Gossypium hirsutumL .29: 514-519.

Brown-Guedira, G.L. 2000. Evaluation of Genetic Diversity of Soybean Introductions and North American Ancestors Using RAPD and SSR Markers. J. Crop sci. 40: 815-823.

Bertamini, M., N. Nedunchezhian, F. Tomasi and S. Grando. 2002. Phytoplasma (Stolbur subgroup (Bois Noir$\mathrm{BN})$ ) infection inhibits photosynthetic pigments, ribulose-1, 5-bipho-sphate carboxylase and photosynthetic activities in field grown grapevine .J. Mol. Plant Pathol. 61:357-366.

Brubaker, C. L., Bourland, F. M., \& Wendel, J. F. (1999). The origin and domestication of cotton.

Campbell, B. T., Saha, S., Percy, R., Frelichowski, J., Jenkins, J. N., Park, W., \& Du, X. (2010). Status of the global cotton germplasm resources. Crop sci., 50(4), 11611179.

Dry, I. B., J. E. Rigden, L. R. Kraken, P.M. Molineux and M. Rezaian.1993. Nucleotide sequence and genome organization of tomato leaf curl Gemini virus. J. Virol. 74: 147-151.

Dieng, H., T. Satho, A.A. Hassan, A.T. Aziz, R.E. Morales, S.A. Hamid, F. Miake and S. Abu-Bakr. 2011. Peroxidase activity after viral infection and whitefly infestation in juvenile and mature leaves of Solanum lycopersicum. J. Phytopathol.159:707-712.
Endrizzi, J. E., Turcotte, E. L., \& Kohel, R. J. (1985). Genetics, cytology, and evolution of Gossypium. In Adv. in gen. (Vol. 23, pp. 271-375). Academic Press.

Edwards, R.A. and F. Rohwer .2005. Viral metagenomics.

Nat. Rev. Microbiol. 3(6): 504-510.

Frary, A., Göl, D., Keleş, D., Ökmen, B., Pınar, H., Şığva, H. Ö. \& Doğanlar, S. (2010). Salt tolerance in Solanum pennellii: antioxidant response and related QTL. BMC plant biol., 10(1), 58.

Favali, M. A., L.S.Toppi, C. Vestena, F. Fossati and R. Musette .2001. Phyto plasmas associated with tomato stolbur disease. 551:93-99.

Farooq, A., J. Farooq, A. Mahmood, A. Shakeel, A. Rehman, A. Batool, M. Riaz, M. T. H. Shahid and S.Mehboob.2011.Overviews of cotton leaf curl virus disease (CLCuD) a serious threat to cotton productivity. Aus. J. Crop Sci., 5: 1823-1831.

Huang, W. E., Li, M., Jarvis, R. M., Goodacre, R., \& Banwart, S. A. (2010). Shining light on the microbial world: the application of Raman microspectroscopy. In Adv. in app. microbial. (Vol. 70, pp. 153-186). Academic Press.

Holt, J., J. Colvi and V. Muniyappa. (1999) Identifying control strategies for tomato leaf curl virus disease using an epidemiological model. J. App. Ecol. 36:1-10.

Hameed, A., M. Iqbal. 2013. Drought induced programmed cell death and associated changes in anti-oxidants, proteases, and lipid peroxidation in wheat leaves. 57:370-374.

Hendrix, B., \& Stewart, J. M. (2005). Estimation of the nuclear DNA content of Gossypium species. Ann. Bot., 95(5), 789-797.

Ismail, R.M., J.F. Zhang and A.M. Abdel-Hamid. 2008. Genetic Diversity in Elite Cotton Germplasm Lines Using Field Performance and RAPD Markers. World Journal of Agricultural Sciences. 4: 369-375.

Iqbal, M., K. Hayat, R.S.A. Khan, A. Sadiqi and N. U. Islam. 2006. Correlation and path coefficient analysis for earliness and yield traits in cotton (G. hirsutum L.). Asian Journal of Plant Sciences. 5:341-344.

Jiang, C.X., R. J. Wright, K.M. Zikr and A.H.1998. Paterson. Polyploidy formation created unique avenues for response to selection in Gossypium (cotton). Proceedings of the National Academy of Sciences. 95(8): 4419-4424.

Khan, J.A., and J. Ahmad. 2005. Diagnosis, monitoring and transmission characters of Cotton leaf curl virus. Sci.88: 1803-1809.

Kale, U.V., H.V. Kalpande, S. N. Annapurve and V. K. Gate. 2007. Yield components analysis in American Cotton (Gossypium hirsutumL.). Journal of Agriculture. 94:156-161

Knight, R.L.1957. Black Arm Disease of Cotton and its Control. In the "Plant Protection Conference 1956". Butterworths Scientific Publications, London. 53-59. 
Kiraly, Z., B. Barna, A. Kecskes and J. Fodor. 2002. Down regulation of anti-oxidative capacity in a transgenic tobacco, which fails to develop acquired resistance to narcotization caused by tobacco mosaic virus. 36:981-991.

Kumari, A., Das, P., Parida, A. K., \& Agarwal, P. K. (2015). Proteomics, metabolomics, and ionomics perspectives of salinity tolerance in halophytes. Frontiers in Plant Science, 6, 537.

Kumar, A., Snehi, S. K., Raj, S. K., Kumar, J., \& Khan, J. A. (2011). Association of Cotton leaf curl Burewala virus and its satellite molecules with leaf distortion symptoms of cotton in India. New Disease Reports, 24(18), 2044-0588.

Lubbers, L. M., Hughes, K. E., Coleman, C. R., Williamson IV, W. P., Berky, C. B., Ward, T. J., .. \& Schumacher, B. S. (2009). U.S. Patent No. 7,611,521. Washington, DC: U.S. Patent and Trademark Office.

Lee, J. J., A.W. Woodward and Z.J. Chen .2007. Gene expression changes and early events in cotton fiber development. Journal of botany. 100: 1391-1401.

Li, Z., X. Wang, Z. Yan, Z. Guiyin, C. Jina. 2008. Assessment of Genetic Diversity in Glandless Cotton Germplasm Resources by Using Agronomic Traits and Molecular Markers. Frontiers of Agriculture in China.2: 245252. Smith, C.W. 1995. Cotton (Gossypium hirsitum L.). Crop Production: Evolution, History, and Technology. John Wiley and Sons, New York. 287349.

Lee, J. A. (1984). Cotton as a world crop. Cotton, (cotton), 125.

Mansoor, S., R.W.Briddon, Y. Zafar and J. Stanley.2003. Gemini virus disease complexes: an emerging threat; Trends in Plants Science. 8(3): 128-134.

Monga, D., P.K. Chakraborty and R. Kranthi. 2011. Cotton leaf Curl Disease in India-recent status and management strategies. Asian Cotton Research and Development Network Held in Lahore.2: 23-25.

Mathews, H. 1987. The changing scene in plant virology. Journal of Phytopathology. 25: 10-23.

Mehetre, S.S., A.R. Aher and V.L. Gawande. 2003. Induced Polyploidy in Gossypium: A Tool to Overcome InterSpecific Incompatibility of Cultivated Tetra-Ploid and Diploid Cottons. Current Sciences. 84: 15101512.

Musetti, R., Paolacci, A., Ciaffi, M., Tanzarella, O. A., Polizzotto, R., Tubaro, F., \& Osler, R. (2010). Phloem cytochemical modification and gene expression following the recovery of apple plants from apple proliferation disease. Phytopathology, 100(4), 390-399.

Maksimov, I., N .Troshina, O. Surina, E. Cherepanova. 2014. Salicylic acid increases the defense reaction against bunt and smut pathogens in wheat. Journal of Plant Interact.9:306-314.

Mehdy, M. C. (1994). Active oxygen species in plant defense against pathogens. Plant physiology, 105(2), and 467.

This publication is licensed under Creative Commons Attribution CC BY. http://dx.doi.org/10.29322/IJSRP.10.05.2020.p10156
Mydlarz LD, Harvell CD. 2006. Peroxidase activity and inducibility in the see fan coral exposed to a fungal pathogen. Comp Biochem Physiol. 10:1016.

Navot, N., E .Picher sky, M. Zeidan, D. Zamir and H. Czosnek .1991. Tomato yellow leaf curl virus: a whiteflytransmitted Gemini virus with a single genomic component. Journal of Virology.185: 151-161.

Nix, A., C. Paull and M.Colgrave .2017. Flavonoid Profile of the Cotton Plant, Gossypium hirsutum.6-4.

Osakabe, Y., Osakabe, K., Shinozaki, K., \& Tran, L. S. P. (2014). Response of plants to water stress. Frontiers in plant science, 5,86 .

Pico, B., Díez, M. J., \& Nuez, F. (1999). Improved diagnostic techniques for tomato yellow leaf curl virus in tomato breeding programs. Plant disease, 83(11), 10061012.

Palumbo, J. C., Horowitz, A. R., \& Prabhaker, N. (2001). Insecticidal control and resistance management for Bemisia tabaci. Crop protection, 20(9), 739-765.

Pesquet, E., \& Lloyd, C. (2011). The Plant Cytoskeleton, Advances in Plant Biology.

Roossinck, M. J., Sabanadzovic, S., Okada, R., \& Valverde, R. A. (2011). The remarkable evolutionary history of endornaviruses. Journal of general virology, 92(11), 2674-2678.

Rajagopalan PA, Naik A, Katturi P, Kurulekar M, Kankanallu RS, Anandalakshmi R. 2012. Dominance of resistance-breaking cotton leaf curl Burewala virus $(\mathrm{CLCuBuV})$ in northwestern India. Arch Virol. 157:855-868. 10.1007/s00705-012-1225-y

Riddle-Bauer, M. 2000. Role of reactive oxygen species and antioxidant enzymes in systemic virus infections of plants. Journal of Phytopathology. 148: 297-302.

Sulman, M., Fox, G., Osman, A., Inkerman, A., Williams, P., \& Michalowitz, M. (2001, September). Relationship between total peroxidase activity and susceptibility to black point in mature grain of some barley cultivars. In Proceeding of the 10th Australian Barley Technical Symposium.

Sattar, M. N., Kvarnheden, A., Saeed, M., \& Briddon, R. W. (2013). Cotton leaf curl disease-an emerging threat to cotton production worldwide. Journal of General Virology, 94(4), 695-710.

Sharma, P., \& Rishi, N. (2007). Cotton leaf curl disease, an emerging whitefly transmissible begomovirus complex. Plant Viruses, 1(1), 127-134.

Saeed, M., Wangzhen, G., \& Tianzhen, Z. (2014). Association mapping for salinity tolerance in cotton ('Gossypium hirsutum'L.) germplasm from US and diverse regions of China. Australian Journal of Crop Science, 8(3), 338.

Sharma, A., A. Murayama, T. Osaki, M. Ikegami (1998): Characterization of virus-specific DNA forms from tomato tissues infected by tobacco leaf curl virus: evidence for a single genomic component producing defective DNA molecules. Plant Pathol. 47, 787 - 793.

Singleton, V. L., \& Rossi, J. A. (1965). Colorimetry of total phenolics with phosphomolybdic-phosphotungstic 
acid reagents. American journal of Enology and Viticulture, 16(3), 144-158.

Song, F. L., R. Gan, Y. Zhang, Y. Xiao, Q. Kuang, and H.B. Li. 2010. Total phenolic contents and antioxidant capacities of selected Chinese medicinal plants. International Journal of Molecular Sciences. 11, 2362-2372.

Siddique, Z., K.P. Akhtar, A. Hameed. 2014. Biochemical alterations in leaves of resistant and susceptible cotton genotypes infected systemically by cotton leaf curl Burewala virus. Journal of Plant Interact .9 (1):702-711.

Shigeoka, S., Ishikawa, T., Tamoi, M., Miyagawa, Y., Takeda, T., Yabuta, Y., \& Yoshimura, K. (2002). Regulation and function of ascorbate peroxidase isoenzymes. Journal of experimental botany, 53(372), 1305-1319.

Tariq, M. 2005. Status of cotton leaf curl virus in the Punjab. Pakistan Cotton Growers.9: 7-9.

Tahir, M. N., I. Amin, R.W.Briddon and S. Mansoor. 2011. The merging of two dynasties - identification of an African cotton leaf curl disease-associated begomovirus with cotton in Pakistan. 6:20-366.

Tornero, P., R. Chao, W. Lutein, S. Dangl. 2002. Large-scale structure, function, analysis, of Arabidopsis RPM1disease resistance protein. 14:435-450.

Van Regenmortel, M. H. V. (2006). Virologists, taxonomy and the demands of logic. Archives of virology, 151(7), 1251.

Verma, U., Piepho, H. P., Ogutu, J. O., Kalubarme, M. H., \& Goyal, M. (2014). Development of zonal agromet models for district-level cotton yield forecasts in haryana state, india. Int. J. Agricult. Stat. Sci, 10(1), 59-65.

Wendel, J. F., \& Grover, C. E. (2015). Taxonomy and evolution of the cotton genus, Gossypium. Cotton, (agronmonogr57), 25-44.

Wendel, J. F., \& Cronn, R. C. (2003). Polyploidy and the evolutionary history of cotton. Advances in agronomy, 78, and 139.

Yoshida, K., P. Kaothien, T. Matsui, A. Kawaka and Shinmyo .2003. Molecular biology and application of plant peroxidase genes. App. Microbiol. Biotechnol. 60:665-670.

Zhou, X., Y. Liu, D.J. Robinson and B.D. Harrison.1998. Four DNA-A variants among Pakistani Isolates of cotton leaf curl virus and their affinities to DNA-A of Gemini virus isolates from okra. Journal of Virology. 79:915-923.

Zhu, S. J., L. Li, J. Chen. 2011. Advance in research and utilization of cotton biotechnology in China.

Zhou, B., Chen, Z., Du, L., Ye, X., \& Li, N. (2012). Correlation between resistance of eggplant and defense-related enzymes and biochemical substances of leaves. African J. Biotechnol. , 11(74), 1389613902. 